\title{
Impact of Etoposide on BRCA1 Expression in Various Breast Cancer Cell Lines
}

\author{
Xi Zhang ${ }^{1} \cdot$ Simone Hofmann $^{1} \cdot$ Nadia Harbeck $^{1} \cdot$ Udo Jeschke $^{1} \cdot$ Sophie Sixou $^{1,2}$
}

Published online: 6 September 2017

(c) The Author(s) 2017. This article is an open access publication

\begin{abstract}
Breast cancer 1 (BRCA1), as a tumor suppressor, exerts an effective influence on protecting DNA integrity to suppress the development of breast cancer (BC). BRCA1 expression is induced in response to DNA-damaging agents such as etoposide. Germline BRCA1 gene mutations are associated with development of hereditary BC. However, besides BRCA-mutated BCs, some sporadic cancers may also exhibit a BRCA-like phenotype, displaying so-called 'BRCAness'. This common phenotype may respond to similar therapeutic approaches as BRCA-mutated tumors and may thus have important implications for the clinical management of these cancers. In order to determine whether and how etoposide regulates the protein levels of BRCA1 in $\mathrm{BC}$ cells, we exposed a panel of five selected cell lines to etoposide, compared the results to untreated control cells, and then stained the cells with the specific, reliable, and reproducible MS110 antibody directed against phosphorylated Ser1423 BRCA1. By evaluating cytoplasmic BRCA1 protein levels, we were able to distinguish three aggressive BC subtypes with BRCAness characteristics. In addition, determination of early and late apoptosis helped to complete the analysis of BRCA1 functions in the DNA damage pathway of aggressive BC. In conclusion, our study
\end{abstract}

Electronic supplementary material The online version of this article (doi:10.1007/s40268-017-0208-6) contains supplementary material, which is available to authorized users.

Sophie Sixou

sophie.doisneausixou@med.lmu.de

1 Department of Obstetrics and Gynecology, Breast Center, Ludwig-Maximilians University of Munich, Maistrasse 11, 80337 Munich, Germany

2 Faculty of Pharmacy, University Paul Sabatier Toulouse III, 31062 Toulouse Cedex 09, France suggested that high cytoplasmic BRCA1 protein levels could be considered as a potential predictive marker for response to chemotherapy in both sporadic and hereditary BC. Tumors with either BRCAness phenotype or germline $B R C A 1$ mutation are both aggressive $\mathrm{BCs}$ associated with poor prognosis and could both be subjected to targeted therapies against $B R C A 1$-mutated $\mathrm{BC}$ in future clinical management strategies.

\section{Key Points}

Treatment of breast cancer (BC) cells with etoposide markedly enhanced both the cytoplasmic breast cancer 1 (BRCA1) and nuclear phosphorylated BRCA1 protein levels in BRCAness phenotype breast cells.

The function of BRCA1 in the DNA damage pathway of aggressive $\mathrm{BC}$ cells may link to apoptosis.

Cytoplasmic BRCA1 expression has potential to be a predictive biomarker in response to chemotherapy in BC.

\section{Background}

Breast cancer (BC) is the leading cause of death among women diagnosed with cancer worldwide [1]. In 2012, it alone comprised $25 \%$ of all cancer cases and $15 \%$ of all cancer deaths among females [2], making it the most 
common female cancer. However, BC is a complex and extremely heterogeneous disease [3]. Thus, a deep understanding of its biology and of certain prognostic factors is of great significance in predicting disease outcome and developing new target therapeutic strategies. Breast cancer 1 $(B R C A 1)$ is a susceptibility gene responsible for hereditary predisposition to BC. Since it was first found to encode a DNA repair enzyme involved in BC susceptibility in 1990 [4], and subsequently was successfully cloned in 1994 [5], BRCAl has received a great deal of attention in BC. It has been mapped to chromosome 17q21 containing 24 exons, encoding a pleiotropic full-length protein of 1863 amino acids in humans [5]. BRCA1 full-length form is the bestdefined BRCAl gene product that contains multiple functional domains, including a highly conserved N-terminal RING domain, two nuclear localization signals located in the exon 11, a serine-glutamine (SQ) cluster between amino acids 1280-1524 [6], and tandem C-terminal BRCA1 (BRCT) domains [7-9]. BRCA1 is a serine phosphoprotein that is regulated in a cell cycle-specific manner [10] and hyper-phosphorylated in response to DNA damage [11-14]. As a tumor suppressor, BRCA1 mediates many different molecular processes including repair of double-strand DNA breaks, transcriptional activation, apoptosis, cell-cycle checkpoint control, and chromosomal remodeling, binds different functional proteins (c-myc, E2F, p53, RAD50, cyclins, CDKs, RNA polymerase, etc.), and suppresses development of BC and ovarian cancers [15-18].

Therefore, genomic sequencing of BRCAl (and $B R C A 2)$ in women with a familial history of one or more incidences of early-onset $\mathrm{BC}$ or ovarian cancer provides a powerful tool to detect disease predisposition. However, the genomic test is expensive and not suitable for detection of sporadic cancers associated with somatic events. Overall, about $9.3 \%$ of female BC patients carry predisposing mutations [19]. Germline mutations of BRCA1 and BRCA2 are responsible for about $50 \%$ of hereditary BC [20, 21]; nevertheless, these mutations account for only $3-8 \%$ of all BCs. Most BCs are sporadic and occur in absence of BRCA1 mutations [22, 23]. In sporadic breast tumors, many researchers have postulated that loss of heterozygosity (LOH) reduces BRCAl messenger RNA (mRNA) and protein levels, induces incorrect subcellular localization [24-27], and impairs methylation of the BRCAl promoter region [28-30]. These events lead to noticeable loss of BRCA1 function and provide evidence for a BRCA1 tumor suppressor function in sporadic forms [31]. Besides BRCA-mutated BC, sporadic cancers may exhibit a socalled 'BRCAness' feature, as they display a BRCAl mutation phenotype without any mutation [32-35]. Nonetheless, BRCAness is generally associated with mutations of other genes of the same signaling pathway. In addition to its involvement in the tumor-suppressing process, BRCA1 is also considered a key player in establishing chemotherapy sensitivity and could thus be considered a predictive factor for patient management [36]. In preclinical and clinical studies, the role of BRCA1 in response to DNA-damaging agents and other types of chemotherapy agents has only partly been elucidated $[37,38]$. To the best of our knowledge, numerous studies have investigated the clinic pathological value of the BRCA1 protein level or of its subcellular localization in clearly defined breast carcinomas, including sporadic and BRCA1-mutated tumors. Nonetheless, in spite of the findings concerning BRCA1 expression, the clinical value of its subcellular localization is still controversial, mostly due to limited techniques and approaches [24, 39-57].

To address this issue, we evaluated BRCA1 nuclear and cytoplasmic expression using immunofluorescence in a panel of cultured breast cell lines with specific properties. In addition, we used etoposide, as a DNA-damaging reagent, to validate its effect on BRCA1 protein regulation, and shed light on BRCA1 expression patterns in representative cell line models of the different BC types with or without etoposide treatment.

\section{Methods}

\subsection{Cell Culture and Etoposide Treatment}

The human adenocarcinoma cell lines MCF-7 and MDAMB-231, both with the BRCA1 wild-type gene, were obtained from the European Collection of Authenticated Cell Cultures (ECACC, Salisbury, UK). The human breast epithelial cell line MCF10A and ductal carcinoma cell line HCC1937 (the latter with BRCAl mutation 5382insC $[58,59])$ were obtained from the American Type Culture Collection (ATCC, Rockville, MD, USA). Human breast ductal carcinoma cell line HCC 3153 with BRCA1 mutation (943ins10) [58] was kindly provided by Adi F. Gazdar (Hamon Center for Therapeutic Oncology Research and Department of Pathology, University of Texas Southwestern Medical Center at Dallas, Dallas, TX, USA). Cryopreservation of cell cultures ranged from passages 1 to 10 . Cells were used during up to 20 passages. To minimize the heterogeneity that arises from different cultured conditions, and in agreement with our own and literature data [60, 61], all cell lines were incubated routinely in Dulbecco's modified Eagle's medium (DMEM) (Biochrom, Berlin, Germany), supplemented with $10 \%$ FCS (Fetal calf serum) (PAA, Pasching, Austria), in a humidified atmosphere of $95 \%$ air and $5 \% \mathrm{CO}_{2}$ at $37{ }^{\circ} \mathrm{C}$. A $50 \mathrm{mM}$ etoposide (Sigma-Aldrich, Saint Louis, MO, USA) solution was prepared in dimethyl sulfoxide (DMSO) (Sigma-Aldrich, Saint Louis, MO, USA) as a stock solution for treatment. In 
preliminary experiments (data not shown), we used different dilutions $(25,50,75$, and $100 \mu \mathrm{M})$ and incubation times $(6,12,24$, and $48 \mathrm{~h})$. As a result of this optimization procedure, we used $100 \mu \mathrm{M}$ of etoposide for $48 \mathrm{~h}$ as unique treatment for the five cell lines. Hence, cells were treated using a 1:500 dilution of the stock solution (etoposide $100 \mu \mathrm{M}$ ) and vehicle (DMSO $100 \mu \mathrm{M}$ ) was used as control in all experiments. For immunofluorescence and apoptosis assays, $5 \times 10^{5}$ cells were grown on slides (ThermoFisher Scientific, Braunschweig, Germany) overnight to $70-80 \%$ confluency, and then treated in $10 \%$ FCS with etoposide solution $100 \mu \mathrm{M}$ for $48 \mathrm{~h}$.

\subsection{Fluorescence Labeling of Breast Cancer 1 (BRCA1) or Phosphorylated BRCA1 with Parallel 4'-6-Diamidino-2-Phenylindole (DAPI) Analysis}

After $48 \mathrm{~h}$ of treatment, culture slides were washed in PBS (phosphate-buffered saline) (Fischer, Saarbrücken, Germany), then immediately fixed in $3.7 \%$ neutral buffered formalin (Fischer, Saarbrücken, Germany) in PBS for $15 \mathrm{~min}$ at room temperature and permeabilized in cold $\left(-20^{\circ} \mathrm{C}\right)$ methanol (Sigma-Aldrich, Steinheim, Germany) for 2 min. After washing in PBS, Ultra V Blocking medium (ThermoFisher Scientific, Fremont, CA, USA) was used for $15 \mathrm{~min}$. This blocking step and all the following steps were performed in a humidified chamber at room temperature. Both antibodies were diluted in Dako Antibody Diluent with Background Reducing Components (Dako, Carpinteria, CA, USA). Cells slides were incubated for $1 \mathrm{~h}$ with either a monoclonal mouse anti-human BRCA1 antibody (1:200 dilution) (MS110, ab16780, Abcam, Cambridge, UK) or a polyclonal rabbit anti-human phosphorylated BRCA1 (1:200 dilution) (phospho S1423, ab47325, Abcam, Cambridge, UK), washed in PBS, incubated for $30 \mathrm{~min}$ with a secondary either goat anti-mouse or anti-rabbit IgG labeled with DyLight488 (Jackson ImmunoResearch, West Grove, PA, USA), and washed in PBS. After drying (30 min, at room temperature), the slides could be mounted with Vectashield Mounting Medium with 4'-6-diamidino-2-phenylindole (DAPI) (Vector Laboratories, Burlingame, CA, USA) before manual analysis with a computerized fluorescence microscope Axioskop (Carl Zeiss Micro Imaging GmbH, Göttingen, Germany) for phase and fluorescence, with $40 \times$ magnification. An AxioCam MR camera and AxioVision software were used to capture, analyze, and save high-resolution images for two fluorescence channels, considered independently or in combination (Carl Zeiss Microscopy, Göttingen, Germany). Definite threshold values of exposure time for BRCA1 were determined. The percentage of cells expressing no $(-)$, low $(+)$, average $(++)$, or high $(+++)$ levels of BRCA1 in cytoplasm (BRCA1) or nuclei (phosphorylated BRCA1) were calculated by analyzing 1500 cells in each slide. Three independent experiments were systematically performed to calculate the mean values and standard error (SE).

\subsection{WST-1 Cell Viability Assay}

After $48 \mathrm{~h}$ of treatment, cell viability was evaluated using the WST-1 reagent (Roche, Mannheim, Germany), based on the enzymatic cleavage of the tetrazolium salt WST-1 to formazan by cellular mitochondria dehydrogenases present in viable cells. Cells $\left(1 \times 10^{4} /\right.$ well $)$ were plated in 96-well plates in DMEM medium containing 10\% FCS. $24 \mathrm{~h}$ later, cells were treated or not in $10 \%$ FCS with $100 \mu \mathrm{mol}$ of etoposide. After $48 \mathrm{~h}$, WST-1 reagent was added to the medium according to the manufacturer's instructions. After $30 \mathrm{~min}$, the absorbance of the samples was measured using the microplate reader (MRX, DYNEX Technologies, Denkendorf, Germany) at $450 \mathrm{~nm}$ wavelength. The relative cell viability percentage in each cell line was calculated by comparison to that of the control group. Each condition was performed three times in each experiment and for each cell line, and three independent experiments were then performed to calculate the mean values and SE.

\subsection{In Situ Nick-Translation (ISNT) Apoptosis Assay}

After $48 \mathrm{~h}$ treatment, the in situ nick-translation (ISNT) technique was used to stain DNA fragmentation and apoptotic bodies in the cells for late apoptosis detection [62]. Slides were washed in PBS, then immediately fixed in acetone (Sigma-Aldrich, Steinheim, Germany) for $10 \mathrm{~min}$. After rinsing with distilled water, the endogenous peroxidase was quenched with $0.3 \%$ hydrogen peroxide for $10 \mathrm{~min}$. After being rinsed in distilled water again, the slides were equilibrated in nick buffer $\left(0.1 \mathrm{M}\right.$ Tris, $0.1 \mathrm{M} \mathrm{MgCl}_{2}$, $0.75 \% \beta$-mercaptoethanol, $2 \mathrm{mg} / \mathrm{mL}$ bovine serum albumin [BSA]) at room temperature for $10 \mathrm{~min}$. ISNT was then carried out by incubating the slides with deoxynucleotides (dNTPs) (1:50 dilution) (ThermoFisher Scientific, Fremont, CA, USA) and biotinylated 14-deoxyadenosine triphosphate (dATP) (1:20 dilution) (ThermoFisher Scientific, Fremont, CA, USA) diluted in nick buffer for $50 \mathrm{~min}$ at $37^{\circ} \mathrm{C}$. Terminating buffer $(0.3 \mathrm{M}$ sodium chloride and $0.03 \mathrm{M}$ sodium citrate) was used to rinse the chamber slides at room temperature for 15 min. After washing in PBS and 1\% FCS PBS for $10 \mathrm{~min}$ each, slides were incubated with extravidinperoxidase (Sigma, Steinheim, Germany) at room temperature for $30 \mathrm{~min}$. AEC-substrate (Dako, Glostrup, Denmark) was used for color development. Afterwards, the slides were counterstained with Mayer's hemalum (Merck, Darmstadt, 
Germany), then immediately mounted with Aquatex (Merck, Darmstadt, Germany) before manual analysis with a Diaplan light microscope (Leitz, Wetzlar, Germany), with $10 \times$ and $40 \times$ magnifications. The late apoptosis ISNT was calculated by analyzing 1500 cells in each slide. Three independent experiments were systematically performed to calculate the mean values and SE.

\subsection{M30 Cyto Death Apoptosis Assay}

The M30 cyto Death assay was developed to detect caspase-cleaved Cytokeratin 18, which is one of the earliest apoptosis markers in epithelial cells [63, 64]. After treatment, cells were immediately fixed in pure methanol at $-20{ }^{\circ} \mathrm{C}$ for $30 \mathrm{~min}$, washed in washing buffer $(0.1 \%$ PBSTween) and blocked. Afterwards, cells were incubated with a mouse monoclonal antibody (1:25 dilution) (clone M30, Roche, Mannheim, Germany) overnight at $4{ }^{\circ} \mathrm{C}$ in a humidified chamber and then with a secondary goat antimouse IgG labeled with DyLight488. After drying (30 min at room temperature), the slides were mounted with Vectashield Mounting Medium with DAPI (Vector Laboratories, Burlingame, CA, USA) before manual analysis with a computerized fluorescence microscope Axioskop (Carl Zeiss Micro Imaging GmbH, Göttingen, Germany) with $40 \times$ magnification. The early apoptosis by M30 cyto Death staining was calculated by analyzing 1500 cells in each slide. Three independent experiments were systematically performed to calculate the mean values and SE.

\subsection{Statistical Analysis}

IBM SPSS ${ }^{\circledR}$ Statistics for Windows, Version 24.0 (IBM, Ehningen, Germany) was used for collection, processing, and statistical data analysis. The student's $t$ test was performed for comparison between control and treated group in each cell line. $p$ values $\leq 0.05$ were considered statistically significant.

\section{Results}

\subsection{High Cytoplasmic BRCA1 Protein Levels in Aggressive Breast Cancer (BC) Cell Lines}

To gain insights into the importance of BRCA1 expression, we characterized and compared five representative breast cell lines with or without etoposide treatment. BRCA1 protein levels were investigated by immunofluorescence in the human breast normal cell line MCF10A and in four human BC cell lines: MCF-7 (wild-type BRCA1), MDAMB-231 (wild-type BRCA1, but 'BRCAness' phenotype),
HCC1937, and HCC3153 (both BRCA1 mutated). BRCAl mutations in the HCC1937 and HCC 3153 cells were in exons 20 and 11, respectively, and the mutated BRCA1 still includes the epitope of the MS110 antibody, with truncation sites far away from the $\mathrm{N}$-terminal end $[58,65]$. Staining results are presented in Fig. 1a. The original $40 \times$ magnification shows that in control cells, BRCA1 was expressed in the nucleus as well as in the cytoplasm. The enlarged pictures show higher BRCA1 protein levels in the cytoplasm compared with the nuclei of each cell line. For etoposide-treated cells, original magnifications and enlargements demonstrate higher nuclear and cytoplasmic BRCA1 protein levels than in controls, with a more dramatic effect in cytoplasm. Because of this obvious visual difference, we concentrated on solely analyzing BRCA1 cytoplasmic staining to better clarify and quantify the etoposide effect. We counted 1500 cells in each cell slide and evaluated the intensity of BRCA1 cytoplasmic protein levels (no $[-]$, low $[+]$, average $[++]$, and high $[+++]$ ) among all cell lines with or without etoposide treatment (Electronic Supplementary Material Table 1 for all data; Fig. $1 \mathrm{~b}$ for cytoplasmic high expressions). It is noteworthy that within each cell line, cells did not exhibit the same intensity of BRCA1 cytoplasmic staining. Moreover, very few cells exhibit no fluorescence intensity at all $(3.3 \%$ in untreated MCF-10A and 7\% in untreated MCF-7). In the control groups, all five cell lines were found with predominantly low or average protein levels: 71.4 and $80.0 \%$ of cells expressing low BRCA1 cytoplasmic staining in MCF-10A and MCF-7 cells; 81, 92.4, and 84.9\% of cells expressing low or average staining in MDA-MB-231, HCC1937 and HCC3153 cells, respectively. In the untreated cells, a certain percentage of the population expressed only high levels of cytoplasmic BRCA1 in the MDA-MB-231, HCC1937, and HCC3153 cells (19.1, 7.6, and $15.1 \%$, respectively).

After etoposide treatment, all cell lines showed stronger BRCA1 cytoplasmic staining; in particular, the same MDA-MB-231, HCC1937, and HCC3153 cells expressed high of cytoplasmic BRCA1 levels with $80.4 \%$ $(p=0.005), 70.6 \%(p=0.002)$, and $80.7 \%(p=0.01)$, respectively, thus demonstrating a significant rise in the highest protein levels in the entire population (only 1.4\% of the HCC1937 still expressed a low cytoplasmic expression, but no cells in the MDA-MB-231 and HCC3153). Besides, only $2.3 \%(p=0.02)$ and $11 \%(p=0.003)$ of the MCF$10 \mathrm{~A}$ and MDA-MB-231 cells reached such high cytoplasmic expression, but $50.8 \%(p=0.05)$ of the MCF-10A cells and $67.9 \%(p=0.009)$ of the MCF-7 cells now expressed intermediate intensities, demonstrating the same action of etoposide-still significant, but to a lower extent than in the three other cell lines. In summary, high cytoplasmic BRCA1 expression characterizes only a minority 


\section{A $\frac{\text { MCF10A }}{\text { Normal }} \frac{\text { MCF-7 }}{\text { Sporadic BC }} \frac{\text { MDA-MB-231 }}{\text { HCC1937 }} \frac{\text { HCC3153 }}{\text { BRCA1 mutated hereditary BC }}$}

\section{CONTROL}
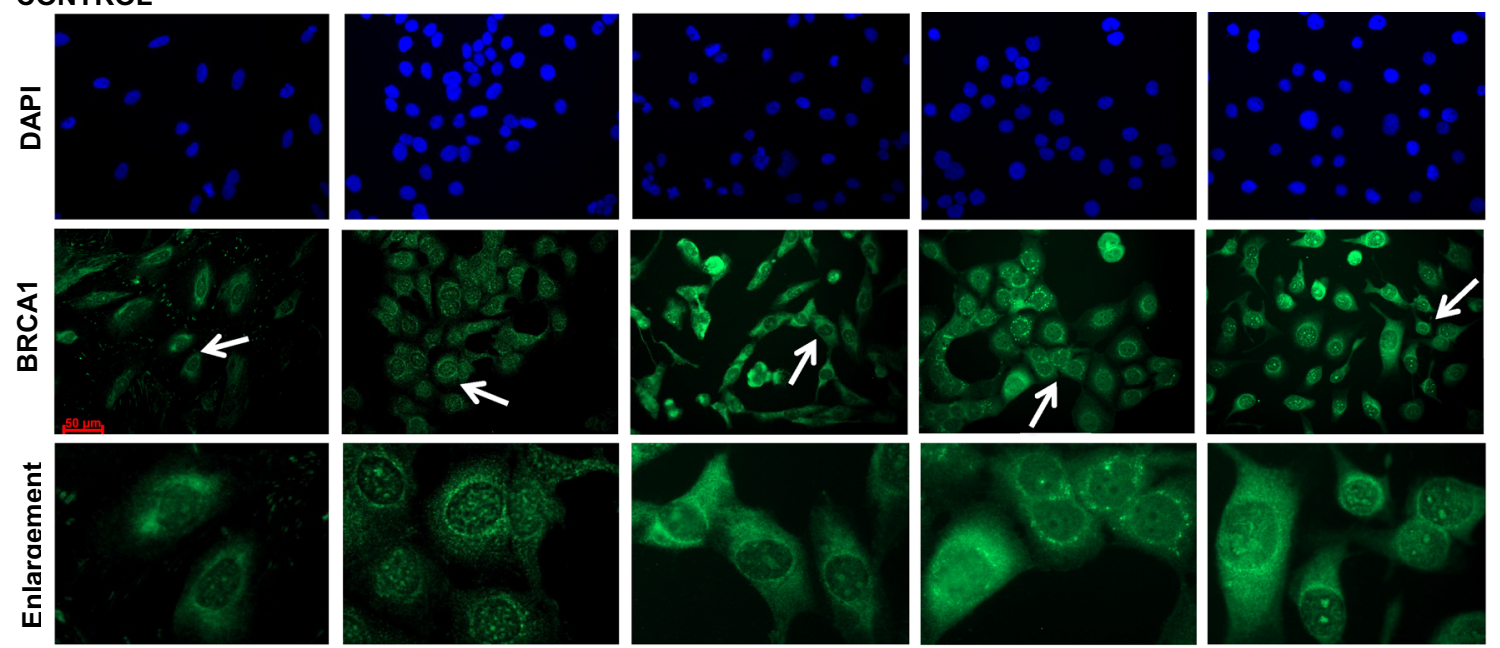

\section{ETOPOSIDE}
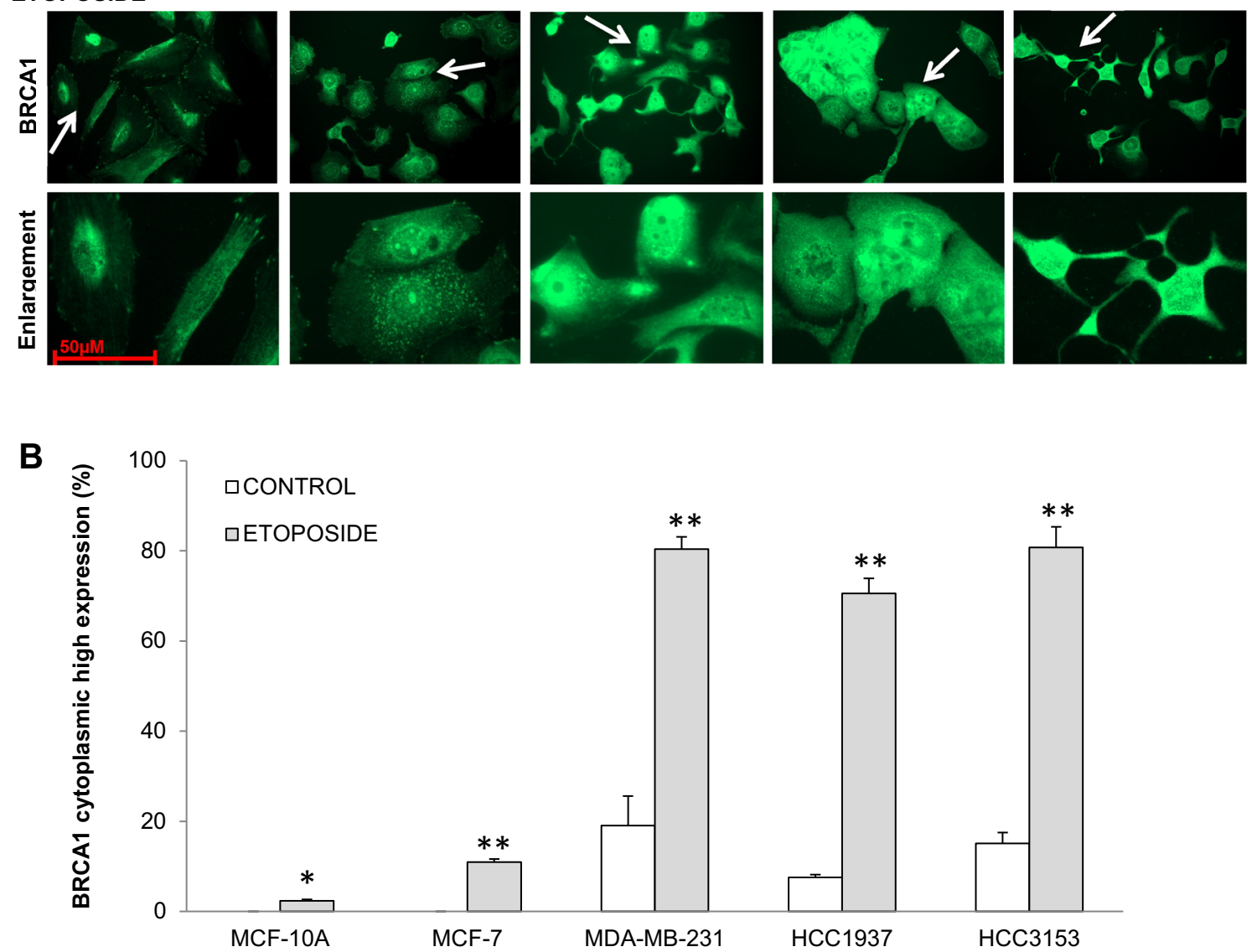

Fig. 1 BRCA1 expression in control and etoposide-treated breast cancer cell lines. Breast cancer cell lines were treated (ETOPOSIDE) or not (CONTROL) with $100 \mu \mathrm{M}$ of etoposide for $48 \mathrm{~h}$, then immunostained with BRCA1 antibody. a Immunofluorescence labelling of BRCA1 (green) was performed together with DAPI nuclear staining (blue). White arrows indicate enlargement parts. Original magnification before enlargement, $\times 40$. Scale bar $50 \mu \mathrm{m}$. b The percentage of cells exhibiting high BRCA1 cytoplasmic staining after analysis of 1500 cells for each experiment (mean value and standard error, $n=3$ ). The correlation is statistically significant for $* p \leq 0.05$, ** $p \leq 0.01$, or *** $p \leq 0.001$. BC breast cancer, BRCAl breast cancer 1, DAPI 4'-6-diamidino-2-phenylindole 
of cells in the three more aggressive untreated cell lines (MDA-MB-231, HCC1937, and HCC3153) and etoposide treatment induces a dramatic increase of these cytoplasmic protein levels in all cell lines. For the less aggressive, hormone-dependent model of BC (MCF-7 cells) and for the normal breast cells (MCF-10A model), this specific high cytoplasmic BRCA1 expression only appears in a minority of the etoposide-treated cells.

\subsection{High Nuclear Phosphorylated BRCA1 Protein Levels in Aggressive Etoposide-Treated BC Cell Lines}

Phosphorylation of BRCA1 is regulated during the cell cycle and in response to DNA damage. We then studied phosphorylated BRCA1 expression, for the five cell lines and in the conditions described in Sect. 3.1 (Fig. 2a). We clearly observed that, in contrast to BRCA1 expression, the phosphorylated BRCA1 staining was all nuclear, with basal protein levels in all cells of the five untreated cell lines. We then semi-quantified the nuclear protein levels of phosphorylated BRCA1, according to the various intensities (again low $[+]$, average $[++]$, or high $[+++]$ ), as presented in Electronic Supplementary Material Table 2 for all data and in Fig. $2 \mathrm{~b}$ for nuclear high expressions. Untreated cells expressed predominantly low/average levels of phosphorylated BRCA1: 100\% of the MCF10A, 94.6\% of the MCF-7, 91.7\% of the MDA-MB-231, 98.5\% of the HCC1937, and $88.1 \%$ of the HCC3153. Although very rare in any untreated cell line, the high protein levels of nuclear phosphorylated BRCA1, were nonetheless slightly increased in all cell lines after etoposide treatment to $3.2 \%(p=0.04)$ of the MCF-10A, $8.4 \%(p=0.12)$ of the MCF-7, most notably and significantly in $71.5 \%$ $(p=0.007)$ of the MDA-MB-231, 70.8\% $(p=0.001)$ of the HCC1937, and 70.4\% ( $p=0.003)$ of the HCC3153. MCF-10A and MCF-7 cells still exhibited significant low nuclear phosphorylated BRCA1 staining (61 and 46.3\%, respectively). In summary, high nuclear protein levels of phosphorylated BRCA1 predominantly characterize the three more aggressive cell lines (MDA-MB-231, HCC1937, and HCC3153) after etoposide treatment.

\subsection{Effect of Etoposide on Cell Viability of Breast Cancer Cell Lines}

To further investigate the effect of etoposide, cell viability was determined by WST-1 assay. As demonstrated in Fig. 3, etoposide inhibited the viability of all five cell lines at a concentration of $100 \mu \mathrm{M}$. Nonetheless, a significant minor effect was observed on the normal breast cell model MCF-10A (87.4\% viability; $p=0.05)$ compared to dramatic effects on all the BC cell lines: $35.9 \%(p=0.004)$
MCF-7, $22.6 \% \quad(p=0.0001) \quad$ MDA-MB- $231, \quad 33.2 \%$ $(p=0.005) \mathrm{HCC} 1937$, and $30.4 \%(p=0.03) \mathrm{HCC} 3153$.

\subsection{Effect of Etoposide on Late and Early Apoptosis}

We then wanted to correlate the viability results to apoptosis and performed in parallel assays for late apoptosis analysis by ISNT and for early apoptosis by M30 staining using conditions already described (Fig. 4a, b, respectively). The rate of late apoptosis (Fig. 4c) detected in the untreated and etoposide-treated MCF10A cells had a similar mean value of 0.5 and $0.6 \%(p=0.6)$, respectively, demonstrating that etoposide did not significantly stimulate apoptosis of the normal breast cell model MCF-10A. The normal rate of apoptosis in the untreated MCF-7, MDAMB-231, HCC1937, and HCC3153 had minimal means of $1,0.9,1$, and $1.1 \%$, respectively, while exposure to etoposide significantly increased apoptosis in MCF-7, and to a higher extent in MDA-MB-231, HCC1937, and HCC3153 to $2.4 \%(p=0.009), 4.3 \%(p=0.005), 3.3 \%(p=0.01)$, and $3.1 \%(p=0.006)$, respectively.

The rates of early apoptosis were found to be very similar to those of late apoptosis (Fig. 4d). The normal breast model, MCF10A cells, control or treated, again had a similar mean value of 0.8 and $0.9 \%(p=0.74)$, respectively. Besides, the normal rates of apoptosis in the four untreated BC cell lines were confirmed to be very low, inferior to $2 \%$, whereas they were significantly elevated to $2.7 \%(p=0.0005), 6.5 \%$ ( $p=0.004), 6.4 \%$ ( $p=0.008)$, and $7.0 \%(p=0.001)$ after etoposide treatment (MCF-7, MDA-MB-231, HCC1937, and HCC3153, respectively).

\section{Discussion}

Since the 1990s, the importance of BRCA1 expression and of its subcellular localization as a marker in sporadic BC has been under debate. Chen et al. [49] first reported that BRCA1 was found in the nuclei of epithelial cells, and detected mainly in the cytoplasm of malignant mammary cells. In contrast, Scully et al. [50] showed that BRCA1 was located predominantly in the nuclei of both normal and malignant cells, whereas Jensen et al. [51] contradicted this by stating that BRCA1 was observed in cytoplasm and cell membrane. Following this, there has been a slow stepwise progression in the understanding of the subcellular distribution of BRCA1, often hampered by technical problems attributable to cross-reactivity and low specificity of certain BRCA1 antibodies. In recent years, advanced technologies and approaches enabled to detect more phosphorylated than non-phosphorylated forms of BRCA1 in nuclear and mitochondrial genomes than in cytoplasm [66]. This demonstrated that BRCA1, as a shuttle protein, shuttles 


\section{A $\frac{\text { MCF10A }}{\text { Normal }} \frac{\text { MCF-7 }}{\text { Sporadic BC }} \frac{\text { MCC1937 }}{\text { BRCA1 mutated hereditary BC }}$}
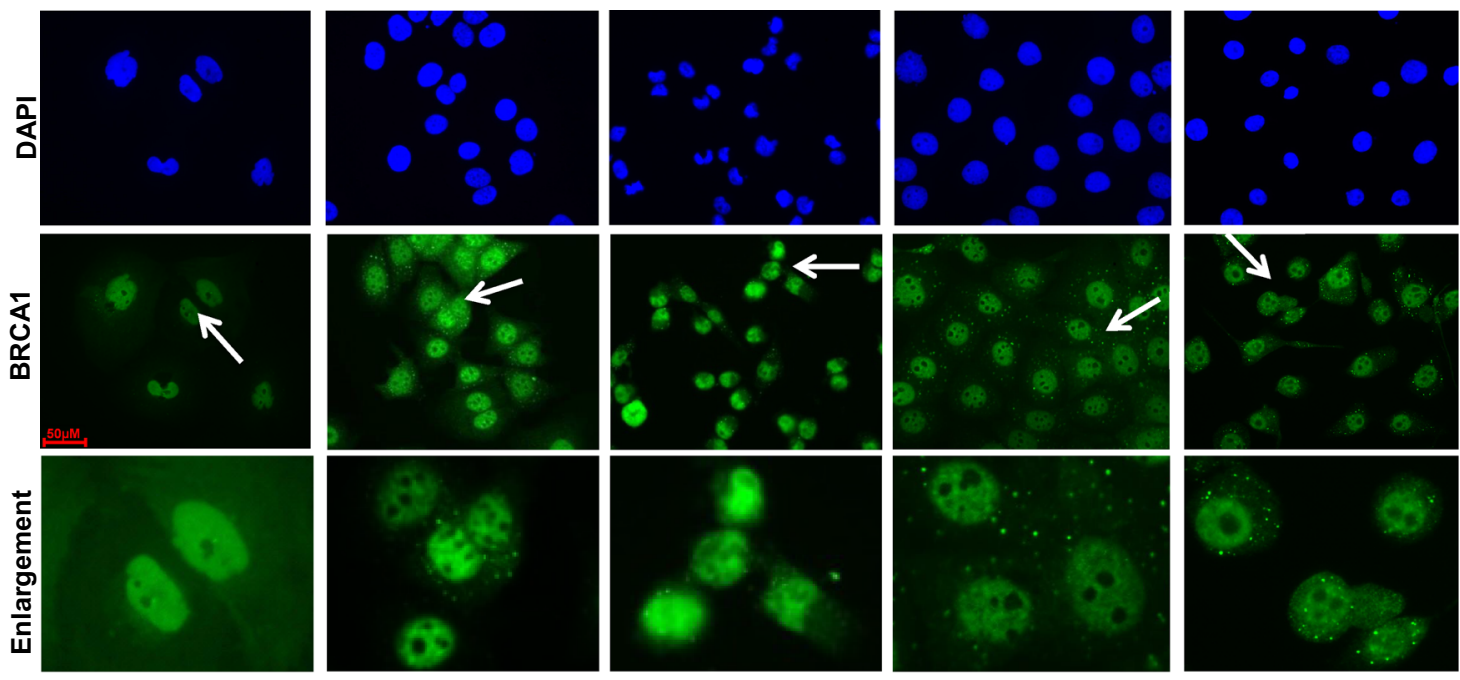

\section{ETOPOSIDE}
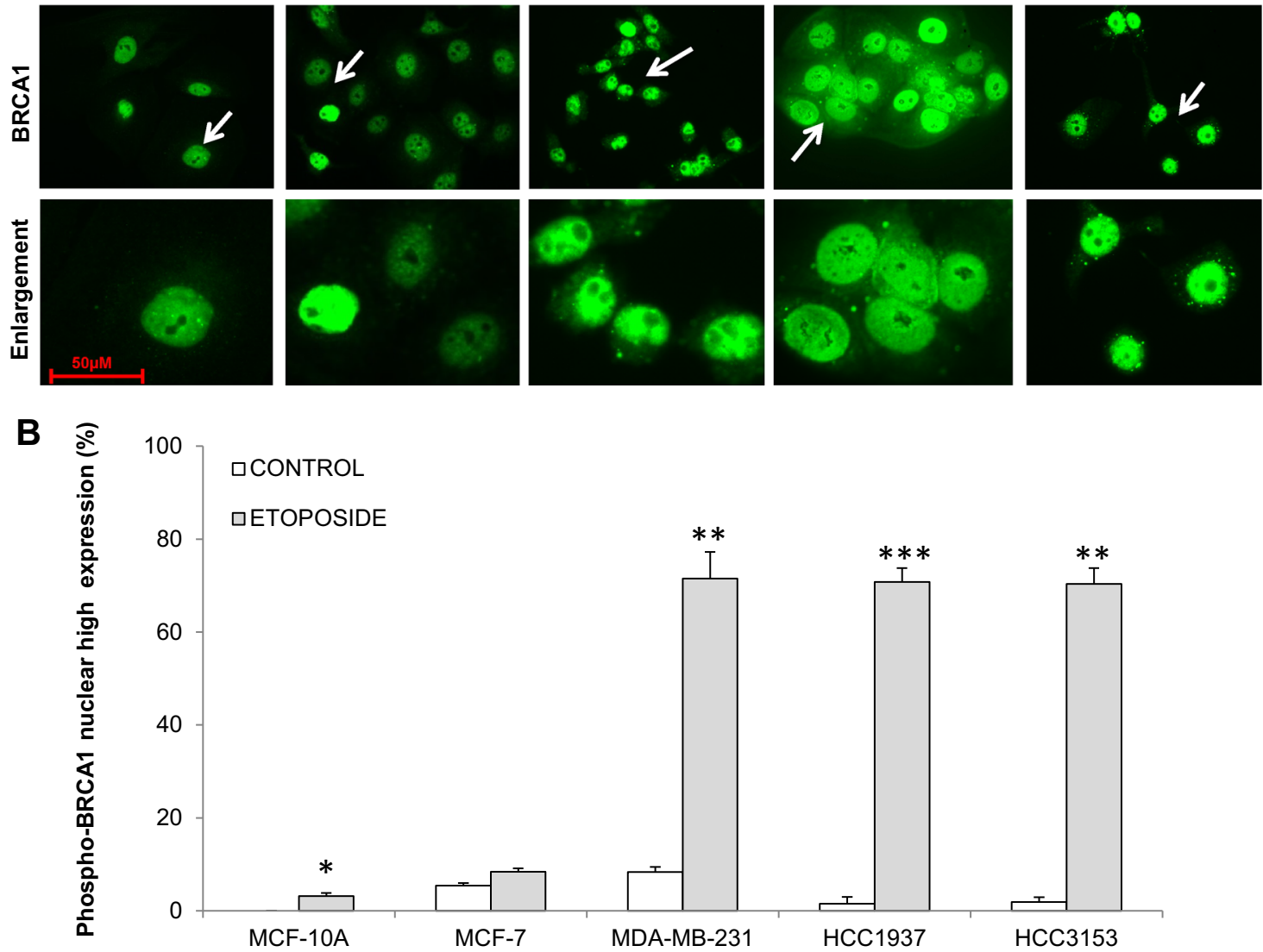

Fig. 2 Phosphorylated BRCA1 expression in control and etoposidetreated breast cancer cell lines. Breast cancer cell lines were treated (ETOPOSIDE) or not (CONTROL) with $100 \mu \mathrm{M}$ etoposide for $48 \mathrm{~h}$, then immunostained with phosphorylated BRCA1 antibody. a Immunofluorescence labelling of phosphorylated BRCA1 (green) was performed together with DAPI nuclear staining (blue). White arrows indicate enlargement parts. Original magnification before enlargement, $\times 40$. Scale bar $50 \mu \mathrm{m}$. b The percentage of cells exhibiting high BRCA1 nuclear staining after the analysis of 1500 cells for each experiment (mean value and standard error, $n=3$ ). The correlation is statistically significant for $* p \leq 0.05, * * p \leq 0.01$, or $* * * p \leq 0.001$. BC breast cancer, BRCAl breast cancer 1, DAPI 4'-6diamidino-2-phenylindole 
Fig. 3 Viability of etoposidetreated breast cancer cell lines. Breast cancer cell lines were treated (ETOPOSIDE) or not (CONTROL) with $100 \mu \mathrm{M}$ etoposide for $48 \mathrm{~h}$, then cell viability was analyzed by WST1. The quantitative assessment of viability is presented as the mean value and standard error $(n=3)$. The correlation is statistically significant for $* p \leq 0.05, * * p \leq 0.01$, or $* * * p \leq 0.001$

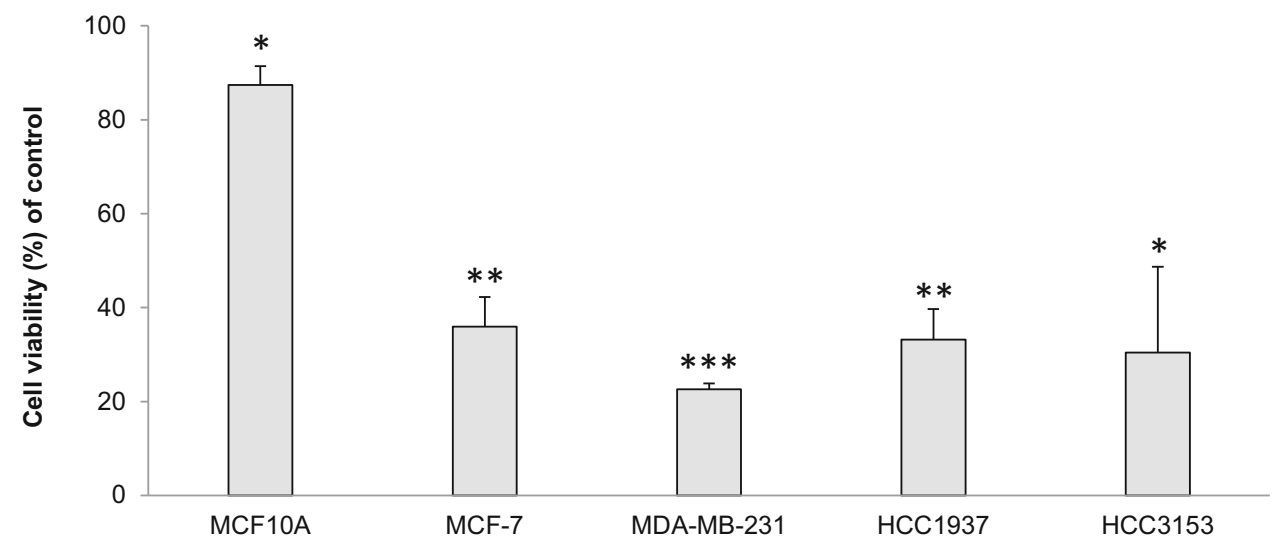

between specific sites within the nucleus and cytoplasm, including DNA repair foci, centrosomes, and mitochondria, and uses its different transport sequences to form distinct protein complexes with various protective roles [67, 68]. However, little is known about how BRCA1 shuttling between the nucleus and cytoplasm is controlled [69]. The specificity of the antibodies selected for BRCA1 detection is also a key point to explore. Wilson et al. [24] first tried to comprehensively characterize 19 anti-BRCA1 antibodies, suggesting that the monoclonal antibody MS110 (Ab-1), targeting the 304 first amino acids from the N-terminal end of BRCA1, is highly specific and allows evaluation of BRCA1 localization and relative protein levels in normal and malignant human breast and ovarian tissues. PerezValles et al. [70] demonstrated that this MS110 antibody gives the most accurate, reliable, and reproducible results in familial and sporadic non-BRCA1 associated breast carcinomas among a four-antibody panel. Using the same MS110 antibody, Milner et al. [71] proposed the measurement of nuclear BRCA1 expression by immunohistochemistry (IHC) on breast and ovarian tumor tissue sections, as patient selection biomarker by focusing exclusively on cells in the $\mathrm{S} / \mathrm{G} 2$ phase where BRCA1 protein staining is expected. Wei et al. [72] aimed to investigate the associations of BRCA1 nuclear expression and clinic pathological characteristics in young Chinese BC patients, and Mylona et al. [47] applied IHC on sporadic $\mathrm{BC}$ patients to explore a different prognostic significance of BRCA1 protein, according to its subcellular distribution. In this study, we further investigated BRCA1 protein levels, by selecting five representative mammary cell lines: MCF-10A, a human normal breast epithelial cell line, which is a widely used in vitro model for studying normal breast cell function and transformation, in spite of some controversies [73], MCF-7 and MDA-MB-231, sporadic $\mathrm{BC}$ models, and $\mathrm{HCC} 1937$ and $\mathrm{HCC} 3153, \mathrm{BRCA1}$ mutated BC cell models. Of note, the MCF-7 cell line is a model of non-aggressive hormone-dependent cancer cells (luminal A), whereas MDA-MB-231, HCC1937, and
HCC3153 belong to aggressive triple-negative BC (TNBC) [74-76]. Regarding the MDA-MB-231 cell line, it shares many features with BRCA1-mutated tumors [77] and is associated to the BRCAness phenotype, defined as a phenocopy of $B R C A 1$ or $B R C A 2$ mutations, initially different from $B R C A 1$ mutations [32]. We selected the widely used antibody MS110 [24, 70-72, 78, 79] and demonstrated BRCA1 protein levels in both the nucleus and cytoplasm of the five normal and cancerous subtypes, which is consistent with other reports [47, 68, 80-83]. In this article, we wanted to detect whether BRCA1 protein expression-irrespective of $B R C A 1$ gene mutation-could differentiate BC subtypes: normal/sporadic/BRCA1-mutated or aggressive/non-aggressive. Some sporadic BC cell lines have no mutation of the BRCA1 gene, such as MDA-MB-231, but nonetheless exhibit BRCAness. Consequently, we aimed to define the relationship between BRCA1 expression and different types BC cell lines. As all cell lines were observed to express predominantly null, low, or average protein levels of BRCA1, with heterogeneous expressions within each cell line, it made it difficult to differentiate $\mathrm{BC}$ subtypes using either nuclear or cytoplasmic BRCA1 protein levels. Nonetheless, it is noteworthy that $7-19 \%$ of cells expressed high levels of cytoplasmic BRCA1 only in the three more aggressive TNBC cell lines.

Etoposide, as topoisomerase II poison, induces doubleand single-strand breaks in DNA [84]. This plant alkaloid is an oral drug used eventually in anthracycline and taxane pre-treated metastatic BC $[85,86]$ or may be useful in combination with new targeted therapy such as anti-vascular endothelial growth factor (VEGF), histone deacetylase, and DNA damage response (DDR) inhibition treatments [87-90]. In HeLa cervix carcinoma cells and SK-OV-3 ovarian cancer cells, BRCA1 mRNA levels were increased by etoposide treatment [91, 92], while BRCA1 expression displayed only a minimal increase in MCF-7 nuclei [93]. Using the conditions we optimized $(100 \mu \mathrm{M}$ concentration and $48 \mathrm{~h}$ duration), our data demonstrate that etoposide treatment induced higher cytoplasmic BRCA1 
A

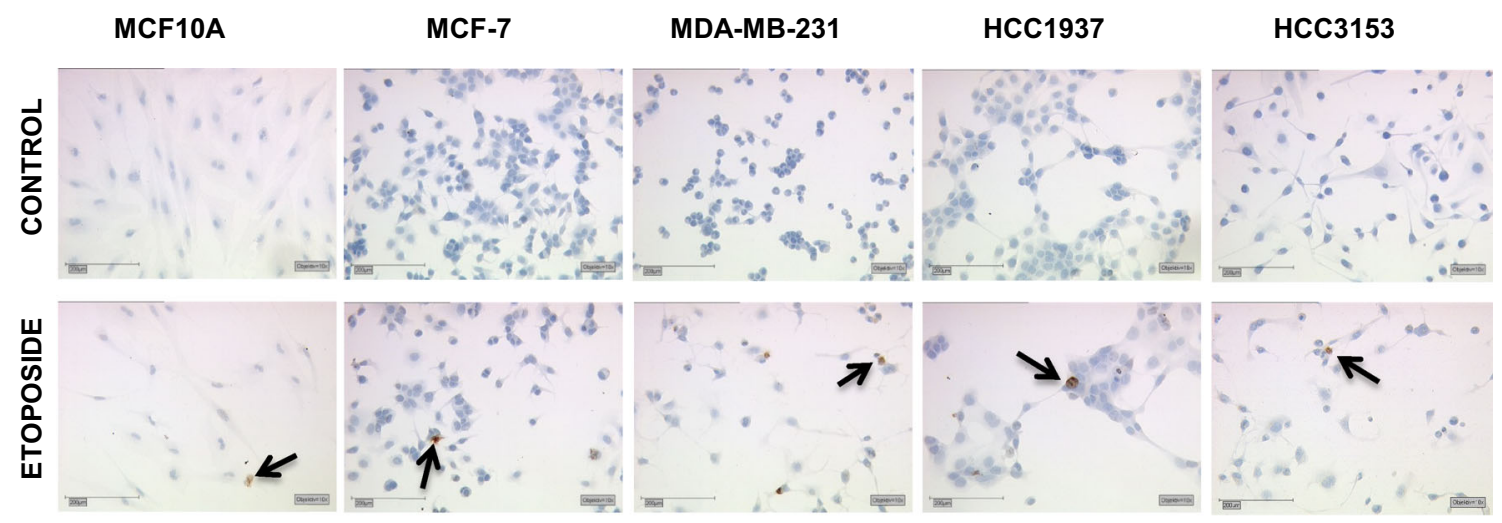

B
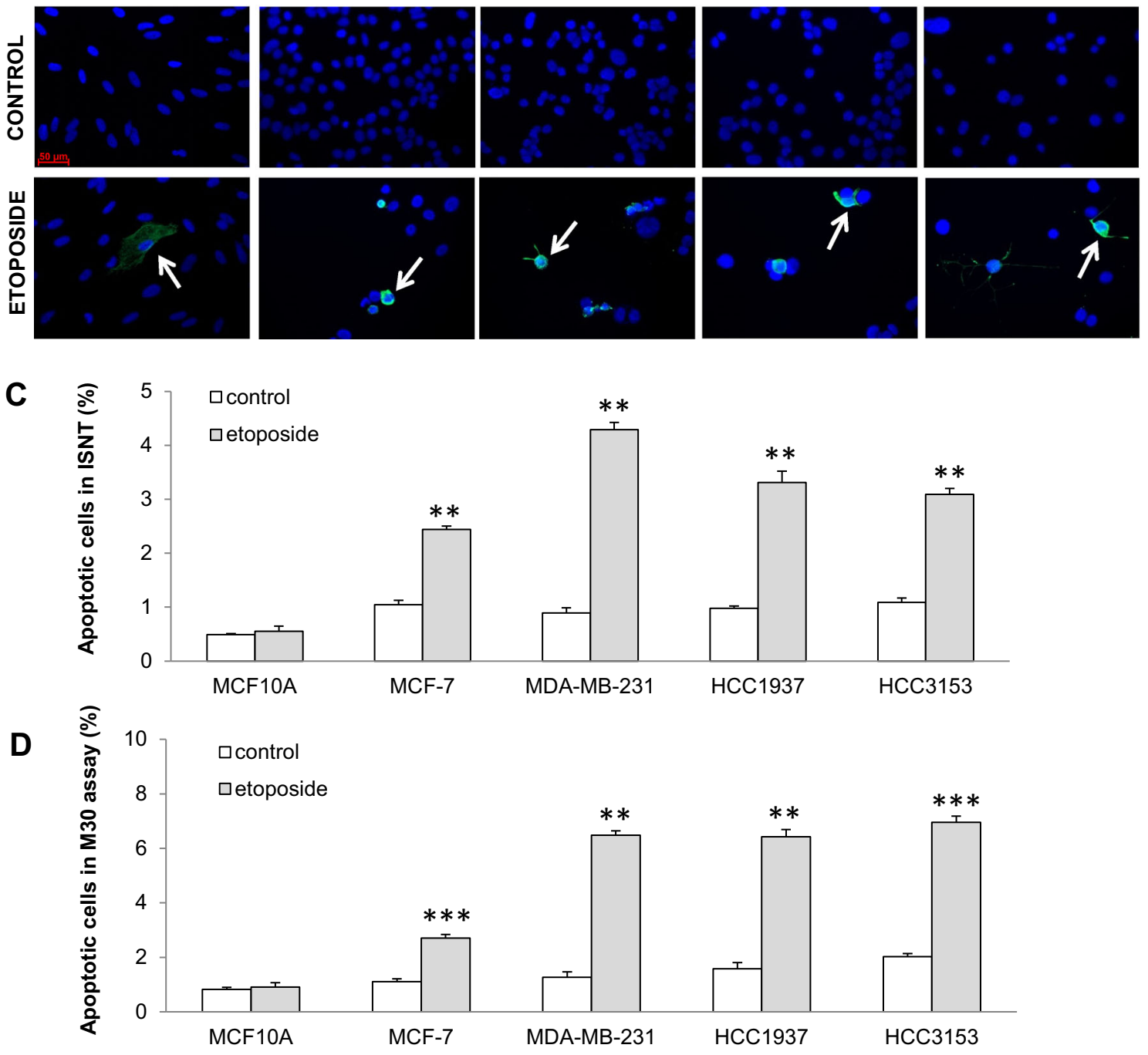

Fig. 4 Late and early apoptosis in etoposide-treated breast cancer cell lines. Breast cancer cell lines were treated (ETOPOSIDE) or not (CONTROL) with $100 \mu \mathrm{M}$ etoposide for $48 \mathrm{~h}$, then apoptosis was detected by in situ nick translation (ISNT) assay for late apoptosis (a) and M30 cyto Death assay for early apoptosis (b). Apoptotic cells were stained brown in (a) (black arrows) and green in (b) (white arrows). The related percentages of apoptotic cells are presented after the analysis of 1500 cells for each experiment in (c) and (d), respectively (mean value and standard error, $n=3$ ). The correlation is statistically significant for $* * p \leq 0.01$ or $* * * p \leq 0.001$ 
levels in the five breast models, with more than $70 \%$ of cells expressing high cytoplasmic levels of BRCA1 in the three aggressive BRCAl-deficient or -mutated cell lines, MDA-MB-231, HCC1937, and HCC3153. In comparison, only 2 and $11 \%$ of the MCF10A and MCF-7 cells expressed these high cytoplasmic levels of BRCA1: BRCA1 cytoplasmic protein levels increased essentially from low to average intensities in most cells of these nontumorigenic MCF-10A and luminal A type MCF-7 models. Thereby, we could distinguish even better the three aggressive TNBC BRCAl-deficient or -mutated cell lines from the normal and luminal subtypes according to BRCA1 cytoplasmic protein levels after using etoposide. Cytoplasmic expression of BRCA1 could be explained by two probable mechanisms: cytoplasmic retention and nuclear export. BRCA1 is trapped in the cytoplasm following overexpression of the anti-apoptotic factor Bcl-2, which redirects BRCA1 to mitochondria and endoplasmic reticulum [94]. In addition, it is notable that $\mathrm{HCC} 1937$ has a phosphatase and tensin homolog on chromosome 10 (PTEN) deletion, and the PTEN inactivation causes an increase in cellular PIP3 levels subsequently activating PI3 K/AKT signaling. This causes an increased expression of several genes for cell growth, cell survival, and cell migration, including BRCA1. AKT1 kinase was also reported to suppress homologous recombination (HR)mediated DNA repair through the cytoplasmic retention of BRCA1 and Rad51 $[95,96]$. Meanwhile, the nuclear export of BRCA1 was directly linked to p53-independent proapoptotic activity [97, 98]. BRCA1 and p53 are both tumor suppressors, which are involved in many cellular processes. BRCA1 has been reported to bind directly to $\mathrm{p} 53$, thereby enhancing p53-mediated transcriptional activation [99-101]. Nuclear run-on experiments and luciferase reporter assays demonstrate that the changes in BRCA1 expression are mainly due to transcriptional repression induced by p53 [102]. Nuclear export of BRCA1 occurred in response to ionizing radiation DNA damage in cells with functional p53 but in cells lacking wild-type p53 BRCA1 was retained in the nucleus [69]. Compared to p53 wildtype MCF-7 and MCF10A, both HCC1937 and MDA-MB231 are p53 mutants, while, to our knowledge, the p53 status of HCC3153 is unknown, although its protein level is negative [103]. In our study, MCF-7 and MCF10A demonstrated an increase of cytoplasmic BRCA1 expression after treatment, which is consistent with the former study. But due to an abnormal BRCA1 and p53 status, the other three cell lines showed much stronger cytoplasmic expressions before treatment. Fedier et al. [104] reported that BRCA1 deficiency in p53-null cells was associated with increased sensitivity to the topoisomerase II poisons etoposide, which could be a mechanism to explain our observations. A study claimed to observe a correlation between cytoplasmic localized BRCA1 and activation of the intrinsic caspase cleavage pathway, in particular after DNA damage [105, 106]. As mentioned earlier, p53, PTEN status, and other tumor suppressors that are also crucial for therapy outcome might have functional interplay with BRCA1 and thus lead to BRCA1 expression alteration and cellular shuttling. To date, the actual mechanism by which cytoplasmic-localized BRCA1 elicits cell death is not fully understood but may be a reason for the increased rate of apoptosis shown in the following apoptosis assay.

As BRCA1 is a serine phosphoprotein regulated in response to DNA damage [11], it has been reported that DNA damage induces both nuclear redistribution of BRCA1, which may also explain increased cytoplasmic staining and an increased phosphorylation of the protein through DNA damage-activated kinases [14, 107, 108]. Several phosphorylation sites have been identified under these conditions, including Ser-1423 [109-111]. We used phospho-Ser-specific antibodies recognizing the Serine in position 1423 of BRCA1 to further explore the regulation of BRCA1 phosphorylation in non-treated and etoposidetreated cells. Our study demonstrated that phosphorylated BRCA1 was mainly located in the nuclei, before and after treatment. BRCA1 being a serine phosphoprotein regulated in a cell cycle-specific manner, its phosphorylation starts when cells enter S-phase. Phosphorylated BRCA1 then accumulates in the nucleus where it functions in the cellular response to DNA damage and regulates specific processes including cell cycle checkpoint activation, DNA repair, and chromatin remodeling. Coene et al. [66] also support a universal role for BRCA1 in the maintenance of genome integrity in nucleus. In addition, DNA damage also induces an increased phosphorylation of the protein through DNA damage-activated kinases. Our results reasonably demonstrate the same trend as a low or medium basal nuclear expression of phosphorylated BRCA1 characterized all non-treated cell lines, with no cell line exhibiting high levels of phosphorylated BRCA1. As expected, etoposide treatment moderately increased the percentage of normal and luminal A cells expressing high nuclear levels of phosphorylated BRCA1 (reaching 3.2 and $8.4 \%$, respectively). In contrast, more than $70 \%$ of the TNBC, BRCA1-deficient or -mutated, cells expressed high nuclear phosphorylated BRCA1. This extremely elevated expression may be the result of the inefficiency of the mutated or deficient BRCAl in these cell lines. These results obtained by immunofluorescence for BRCA1 protein levels and phosphorylation status in five different cell lines confirm preliminary data we generated using immunocytochemistry colorimetric, non-fluorescent staining (data not shown). However, samples are pre-treated differently according to the protein analysis technique and this may profoundly influence the ability of a given 
antibody to bind specifically to its target [112]. So in the future, the results and conclusions of our study will have to be extended using alternate protein analysis technique as western-blot. Moreover, manipulation of BRCA1 expression using RNA interference may demonstrate the importance of BRCA1 for prediction of response to DNAdamaging drug.

Our data suggest that etoposide could induce apoptosis, as we observed an obvious reduction, $60-80 \%$, in the four BC cell populations compared to control cells, whereas the normal breast cells exhibited only a slight decrease. We confirmed that etoposide did induce early and late apoptosis among the four BC cell lines, around a two-fold increase for the MCF-7 and three- to five-fold increases in the three aggressive TNBC cell lines. This higher apoptosis induction rate in the BRCAl-deficient/-mutated cells may relate to the higher expression of cytoplasmic BRCA1 and of nuclear phosphorylated BRCA1. All the results we generated strongly suggest that these three aggressive TNBC cell lines might share some identical pathways related to BRCA1 during DNA damage repair. The elevated expression of (phosphorylated) BRCA1 in cytoplasm or nucleus, before or after treatment, may be associated with the prognosis and further studies are needed to develop this approach as diagnostic assay in BC. In the near future, (phosphorylated) BRCA1 could be first analyzed in the tumors of a large cohort of patients with different BRCA1 status. Unlike the two BRCA1-mutated HCC cell lines, MDA-MB-231 is a model of sporadic $\mathrm{BC}$ without BRCAl mutation. But as a member of basal-like BCs (BLBCs), MDA-MB-231 shares many features with BRCAl-mutated tumors [77]. In the meantime, three-quarters of $B R C A l$-associated tumors are BLBCs [113]. Dysfunctions of the BRCA1 pathway detected in BLBCs mainly regards the impairment of doublestrand break (DSB) repair through HR, leading to genomic instability. The hallmark of BLBCs is the 'BRCAness' [32]; previously, the concept of BRCAness referred to the fact that sporadic tumors characterized by reduced or absent BRCA1 expression share the same phenotype of familial BRCA cancers [35]. Over 20 years, a reassessment of the concept of BRCAness was required and nowadays it describes the situation in which an HR repair (HRR) defect exists in a tumor in the absence of a germline $B R C A 1$ or $B R C A 2$ mutation [33]. BRCAness is then a common characteristic for MDAMB-231, HCC1937, and HCC3153. Since the role of $B R C A 1$ in DNA repair is mainly related to the HR, the new proposed biomarker (cytoplasmic BRCA1) should be compared to the classical (Rad-51 foci in cyclin-A positive cells) or even novel HR assays [114, 115].

There is limited information on BRCA2 mutations in the discussed cell lines. Distribution of histologic types of BRCAl-associated BCs differs from sporadic BCs in various aspects: having distinct morphology, being more often medullary-like, being triple negative, and showing a 'basal' phenotype; but BRCA2-associated BCs do not appear to exhibit a specific pathologic phenotype $[18,116]$. In BRCA1-mutant tumors, the capability of DNA damage repair is decreased, which makes tumor cells more sensitive to DNA-damaging drugs than normal $\mathrm{BC}$ cell lines [117]. Consistent with the HRR defect, tumors with BRCAness might also share therapeutic vulnerabilities with germline $B R C A 1$ or $B R C A 2$ mutation tumors, such as sensitivity to platinum-based drugs and then Poly (ADPribose) polymerase inhibitor (PARPi) [118]. It was recently suggested that inhibition of the DDR (cell cycle arrest and DNA repair) could increase the efficacy of conventional DNA-damaging agents. In particular, like PARPi, which targets the DDR in specific tumor cells, it can selectively kill tumor cells carrying $B R C A$ mutations but not normal cells [119].

\section{Conclusion}

To date, BRCA1 protein measurement evaluated as a potential diagnostic and prognostic biomarker for $\mathrm{BC}$ has never reached a consensus. In our study, with etoposide induction, we can better distinguish BRCA1-associated BC cell line representative subtypes by evaluating cytoplasmic BRCA1 protein level. Meanwhile, our results also show that the increased sensitivity of BRCA1-deficient cells to etoposide may be due to the specific DSB created by topoisomerase II. However, a larger set of BC cell lines with specific sensitivity to various DNA damage agents and different levels of cytoplasmic BRCA1 should be characterized to confirm our hypothesis using other accurate and reliable technologies. Therefore, we suggest that cytoplasmic BRCA1 protein levels level could be considered and further explored as a potential predictive marker for response chemotherapy in both sporadic and hereditary BC. Although this evaluation could not specifically help in guiding treatment, we intend to analyze tumor samples through further collaboration with clinicians in the future. Our results also raise several issues concerning the functions of BRCA1 in the DNA damage pathway and biochemical details of signaling conferred by nuclear phosphorylated BRCA1. BRCAness phenotype and germline $B R C A 1$ or $B R C A 2$ mutation tumors are both aggressive BCs with a poor prognosis which could share common clinical management strategies. Many targeted therapies have been developed against $B R C A 1$-mutated $\mathrm{BC}$, of which PARPi are most promising drugs.

Acknowledgements We would like to thank C. Kuhn for technical advice and the China Scholarship Council (CSC) for a scholarship to Xi Zhang's. 
Authors Contributions SS and UJ conceived and designed the project. XZ wrote the paper and performed most experiments. SH assisted with cell culture. SS contributed to manuscript writing and editing. $\mathrm{NH}$ and $\mathrm{UJ}$ conceived the topic and contributed to manuscript editing. SS supervised the research. All authors read and approved the final manuscript.

\section{Compliance with Ethical Standards}

Conflict of Interest Xi Zhang, Simone Hofmann, Nadia Harbeck, Udo Jeschke, and Sophie Sixou declare that they have no conflict of interest.

Funding Sophie Sixou's salary was supported by the University Paul Sabatier in Toulouse (France).

Ethics approval and consent to participate This article does not contain any studies with human participants or animals performed by any of the authors.

Open Access This article is distributed under the terms of the Creative Commons Attribution-NonCommercial 4.0 International License (http://creativecommons.org/licenses/by-nc/4.0/), which permits any noncommercial use, distribution, and reproduction in any medium, provided you give appropriate credit to the original author(s) and the source, provide a link to the Creative Commons license, and indicate if changes were made.

\section{References}

1. Harbeck N, Gnant M. Breast cancer. Lancet. 2017;389(10074):1134-50. doi:10.1016/S0140-6736(16)31891-8.

2. Torre LA, Bray F, Siegel RL, Ferlay J, Lortet-Tieulent J, Jemal A. Global cancer statistics, 2012. CA Cancer J Clin. 2015;65(2):87-108. doi:10.3322/caac.21262.

3. Cadoo KA, Fornier MN, Morris PG. Biological subtypes of breast cancer: current concepts and implications for recurrence patterns. Q J Nucl Med Mol Imaging. 2013;57(4):312-21.

4. Hall JM, Lee MK, Newman B, Morrow JE, Anderson LA, Huey $\mathrm{B}$, et al. Linkage of early-onset familial breast cancer to chromosome 17q21. Science. 1990;250(4988):1684-9.

5. Miki Y, Swensen J, Shattuck-Eidens D, Futreal PA, Harshman $\mathrm{K}$, Tavtigian S, et al. A strong candidate for the breast and ovarian cancer susceptibility gene BRCA1. Science. 1994;266(5182):66-71.

6. Beckta JM, Dever SM, Gnawali N, Khalil A, Sule A, Golding SE, et al. Mutation of the BRCA1 SQ-cluster results in aberrant mitosis, reduced homologous recombination, and a compensatory increase in non-homologous end joining. Oncotarget. 2015;6(29):27674-87. doi:10.18632/oncotarget.4876.

7. Paterson JW. BRCA1: a review of structure and putative functions. Dis Markers. 1998;13(4):261-74

8. Huen MS, Sy SM, Chen J. BRCA1 and its toolbox for the maintenance of genome integrity. Nat Rev Mol Cell Biol. 2010;11(2):138-48. doi:10.1038/nrm2831.

9. Silver DP, Livingston DM. Mechanisms of BRCA1 tumor suppression. Cancer Discov. 2012;2(8):679-84. doi:10.1158/ 2159-8290.CD-12-0221.

10. Ruffner H, Verma IM. BRCA1 is a cell cycle-regulated nuclear phosphoprotein. Proc Natl Acad Sci USA. 1997;94(14):7138-43.

11. Okada S, Ouchi T. Cell cycle differences in DNA damage-induced BRCA1 phosphorylation affect its subcellular localization. J Biol Chem. 2003;278(3):2015-20. doi:10.1074/ jbc.M208685200.

12. Scully R, Chen J, Ochs RL, Keegan K, Hoekstra M, Feunteun J, et al. Dynamic changes of BRCA1 subnuclear location and phosphorylation state are initiated by DNA damage. Cell. 1997;90(3):425-35.

13. Cortez D, Wang Y, Qin J, Elledge SJ. Requirement of ATMdependent phosphorylation of brcal in the DNA damage response to double-strand breaks. Science. 1999;286(5442):1162-6.

14. Lee JS, Collins KM, Brown AL, Lee CH, Chung JH. hCds1mediated phosphorylation of BRCA1 regulates the DNA damage response. Nature. 2000;404(6774):201-4. doi:10.1038/ 35004614 .

15. Somasundaram K. Breast cancer gene 1 (BRCA1): role in cell cycle regulation and DNA repair-perhaps through transcription. J Cell Biochem. 2003;88(6):1084-91. doi:10.1002/jcb.10469.

16. Romagnolo AP, Romagnolo DF, Selmin OI. BRCA1 as target for breast cancer prevention and therapy. Anticancer Agents Med Chem. 2015;15(1):4-14.

17. Noh JM, Choi DH, Baek H, Nam SJ, Lee JE, Kim JW, et al. Associations between BRCA mutations in high-risk breast cancer patients and familial cancers other than breast or ovary. J Breast Cancer. 2012;15(3):283-7. doi:10.4048/jbc.2012.15.3. 283.

18. Narod SA, Salmena L. BRCA1 and BRCA2 mutations and breast cancer. Discov Med. 2011;12(66):445-53.

19. Buys SS, Sandbach JF, Gammon A, Patel G, Kidd J, Brown KL, et al. A study of over 35,000 women with breast cancer tested with a 25-gene panel of hereditary cancer genes. Cancer. 2017;123(10):1721-30. doi:10.1002/cncr.30498.

20. Alli E, Ford JM. BRCA1: beyond double-strand break repair. DNA Repair (Amst). 2015;32:165-71. doi:10.1016/j.dnarep. 2015.04.028.

21. Kuchenbaecker KB, Hopper JL, Barnes DR, Phillips KA, Mooij $\mathrm{TM}$, Roos-Blom MJ, et al. Risks of breast, ovarian, and contralateral breast cancer for BRCA1 and BRCA2 mutation carriers. JAMA. 2017;317(23):2402-16. doi:10.1001/jama.2017. 7112.

22. Lux MP, Fasching PA, Beckmann MW. Hereditary breast and ovarian cancer: review and future perspectives. J Mol Med (Berl). 2006;84(1):16-28. doi:10.1007/s00109-005-0696-7.

23. Kleibl Z, Kristensen VN. Women at high risk of breast cancer: molecular characteristics, clinical presentation and management. Breast. 2016;28:136-44. doi:10.1016/j.breast.2016.05.006.

24. Wilson CA, Ramos L, Villasenor MR, Anders KH, Press MF, Clarke $\mathrm{K}$, et al. Localization of human BRCA1 and its loss in high-grade, non-inherited breast carcinomas. Nat Genet. 1999;21(2):236-40. doi:10.1038/6029.

25. Thompson ME, Jensen RA, Obermiller PS, Page DL, Holt JT. Decreased expression of BRCA1 accelerates growth and is often present during sporadic breast cancer progression. Nat Genet. 1995;9(4):444-50. doi:10.1038/ng0495-444.

26. Sourvinos G, Spandidos DA. Decreased BRCA1 expression levels may arrest the cell cycle through activation of p53 checkpoint in human sporadic breast tumors. Biochem Biophys Res Commun. 1998;245(1):75-80. doi:10.1006/bbrc.1998.8379.

27. Taylor J, Lymboura M, Pace PE, A'Hern RP, Desai AJ, Shousha $\mathrm{S}$, et al. An important role for BRCA1 in breast cancer progression is indicated by its loss in a large proportion of nonfamilial breast cancers. Int J Cancer. 1998;79(4):334-42.

28. Dobrovic A, Simpfendorfer D. Methylation of the BRCA1 gene in sporadic breast cancer. Cancer Res. 1997;57(16):3347-50.

29. Hasan TN, Leena Grace B, Shafi G, Syed R. Association of BRCA1 promoter methylation with rs11655505 (c.2265C $>$ T) variants and decreased gene expression in sporadic breast 
cancer. Clin Transl Oncol. 2013;15(7):555-62. doi:10.1007/ s12094-012-0968-y.

30. Bianco T, Chenevix-Trench G, Walsh DC, Cooper JE, Dobrovic A. Tumour-specific distribution of BRCA1 promoter region methylation supports a pathogenetic role in breast and ovarian cancer. Carcinogenesis. 2000;21(2):147-51.

31. Turner NC, Reis-Filho JS, Russell AM, Springall RJ, Ryder K, Steele D, et al. BRCA1 dysfunction in sporadic basal-like breast cancer. Oncogene. 2007;26(14):2126-32. doi:10.1038/sj.onc. 1210014

32. De Summa S, Pinto R, Sambiasi D, Petriella D, Paradiso V, Paradiso A, et al. BRCAness: a deeper insight into basal-like breast tumors. Ann Oncol. 2013;24(Suppl 8):viii13-21. doi:10. 1093/annonc/mdt306.

33. Lord CJ, Ashworth A. BRCAness revisited. Nat Rev Cancer. 2016;16(2):110-20. doi:10.1038/nrc.2015.21.

34. Livraghi L, Garber JE. PARP inhibitors in the management of breast cancer: current data and future prospects. BMC Med. 2015;13:188. doi:10.1186/s12916-015-0425-1.

35. Turner N, Tutt A, Ashworth A. Hallmarks of 'BRCAness' in sporadic cancers. Nat Rev Cancer. 2004;4(10):814-9. doi:10. 1038/nrc1457.

36. De Luca P, De Siervi A. Critical role for BRCA1 expression as a marker of chemosensitivity response and prognosis. Front Biosci (Elite Ed). 2016;8:72-83.

37. Imyanitov EN, Moiseyenko VM. Drug therapy for hereditary cancers. Hered Cancer Clin Pract. 2011;9(1):5. doi:10.1186/ 1897-4287-9-5.

38. Murray MM, Mullan PB, Harkin DP. Role played by BRCA1 in transcriptional regulation in response to therapy. Biochem Soc Trans. 2007;35(Pt 5):1342-6. doi:10.1042/BST0351342.

39. Seery LT, Knowlden JM, Gee JM, Robertson JF, Kenny FS, Ellis IO, et al. BRCA1 expression levels predict distant metastasis of sporadic breast cancers. Int $\mathrm{J}$ Cancer. 1999;84(3):258-62.

40. Robson M, Gilewski T, Haas B, Levin D, Borgen P, Rajan P, et al. BRCA-associated breast cancer in young women. J Clin Oncol. 1998;16(5):1642-9. doi:10.1200/jco.1998.16.5.1642.

41. Yang Q, Sakurai T, Mori I, Yoshimura G, Nakamura M, Nakamura Y, et al. Prognostic significance of BRCA1 expression in Japanese sporadic breast carcinomas. Cancer. 2001;92(1):54-60.

42. Magdinier F, Ribieras S, Lenoir GM, Frappart L, Dante R. Down-regulation of BRCA1 in human sporadic breast cancer; analysis of DNA methylation patterns of the putative promoter region. Oncogene. 1998;17(24):3169-76. doi:10.1038/sj.onc. 1202248.

43. de Bock GH, Tollenaar RA, Papelard H, Cornelisse CJ, Devilee $P$, van de Vijver MJ. Clinical and pathological features of BRCA1 associated carcinomas in a hospital-based sample of Dutch breast cancer patients. Br J Cancer. 2001;85(9):1347-50. doi:10.1054/bjoc.2001.2103.

44. Lee WY, Jin YT, Chang TW, Lin PW, Su IJ. Immunolocalization of BRCA1 protein in normal breast tissue and sporadic invasive ductal carcinomas: a correlation with other biological parameters. Histopathology. 1999;34(2):106-12.

45. Yoshikawa K, Honda K, Inamoto T, Shinohara H, Yamauchi A, Suga K, et al. Reduction of BRCA1 protein expression in Japanese sporadic breast carcinomas and its frequent loss in BRCA1-associated cases. Clin Cancer Res. 1999;5(6):1249-61.

46. Yang Q, Yoshimura G, Nakamura M, Nakamura Y, Suzuma T, Umemura $\mathrm{T}$, et al. BRCA1 in non-inherited breast carcinomas (review). Oncol Rep. 2002;9(6):1329-33.

47. Mylona E, Melissaris S, Nomikos A, Theohari I, Giannopoulou I, Tzelepis K, et al. Effect of BRCA1 immunohistochemical localizations on prognosis of patients with sporadic breast carcinomas. Pathol Res Pract. 2014;210(8):533-40. doi:10.1016/ j.prp.2014.05.009.

48. Rakha EA, El-Sheikh SE, Kandil MA, El-Sayed ME, Green AR, Ellis IO. Expression of BRCA1 protein in breast cancer and its prognostic significance. Hum Pathol. 2008;39(6):857-65. doi:10.1016/j.humpath.2007.10.011.

49. Chen Y, Chen CF, Riley DJ, Allred DC, Chen PL, Von Hoff D, et al. Aberrant subcellular localization of BRCA1 in breast cancer. Science. 1995;270(5237):789-91.

50. Scully R, Ganesan S, Brown M, De Caprio JA, Cannistra SA, Feunteun $\mathrm{J}$, et al. Location of BRCA1 in human breast and ovarian cancer cells. Science. 1996;272(5258):123-6.

51. Jensen RA, Thompson ME, Jetton TL, Szabo CI, van der Meer $\mathrm{R}$, Helou B, et al. BRCA1 is secreted and exhibits properties of a granin. Nat Genet. 1996;12(3):303-8. doi:10.1038/ng0396-303.

52. Coene E, Van Oostveldt P, Willems K, van Emmelo J, De Potter CR. BRCA1 is localized in cytoplasmic tube-like invaginations in the nucleus. Nat Genet. 1997;16(2):122-4. doi:10.1038/ng0697-122.

53. Marcus JN, Watson P, Page DL, Narod SA, Lenoir GM, Tonin P, et al. Hereditary breast cancer: pathobiology, prognosis, and BRCA1 and BRCA2 gene linkage. Cancer. 1996;77(4):697-709.

54. Wiener D, Gajardo-Meneses P, Ortega-Hernandez V, HerreraCares C, Diaz S, Fernandez W, et al. BRCA1 and BARD1 colocalize mainly in the cytoplasm of breast cancer tumors, and their isoforms show differential expression. Breast Cancer Res Treat. 2015;153(3):669-78. doi:10.1007/s10549-015-3575-0.

55. Tulchin N, Ornstein L, Dikman S, Strauchen J, Jaffer S, Nagi C, et al. Localization of BRCA1 protein in breast cancer tissue and cell lines with mutations. Cancer Cell Int. 2013;13(1):70. doi:10. 1186/1475-2867-13-70.

56. Fraser JA, Reeves JR, Stanton PD, Black DM, Going JJ, Cooke $\mathrm{TG}$, et al. A role for BRCA1 in sporadic breast cancer. Br J Cancer. 2003;88(8):1263-70. doi:10.1038/sj.bjc.6600863.

57. Roehe AV, Boff AL, Damin A. BRCA1 immunohistochemistry assay: can it play a role in assessing sporadic early-onset breast cancer? Breast J. 2012;18(5):500-1. doi:10.1111/j.1524-4741. 2012.01292.x.

58. Kao J, Salari K, Bocanegra M, Choi YL, Girard L, Gandhi J, et al. Molecular profiling of breast cancer cell lines defines relevant tumor models and provides a resource for cancer gene discovery. PLoS One. 2009;4(7):e6146. doi:10.1371/journal. pone.0006146.

59. Elstrodt F, Hollestelle A, Nagel JH, Gorin M, Wasielewski M, van den Ouweland A, et al. BRCA1 mutation analysis of 41 human breast cancer cell lines reveals three new deleterious mutants. Cancer Res. 2006;66(1):41-5. doi:10.1158/0008-5472. CAN-05-2853.

60. Jiang H, Chen C, Sun Q, Wu J, Qiu L, Gao C, et al. The role of semaphorin $4 \mathrm{D}$ in tumor development and angiogenesis in human breast cancer. Onco Targets Ther. 2016;9:5737-50. doi:10.2147/OTT.S114708.

61. Bock C, Rack B, Kuhn C, Hofmann S, Finkenzeller C, Jager B, et al. Heterogeneity of ERalpha and ErbB2 status in cell lines and circulating tumor cells of metastatic breast cancer patients. Transl Oncol. 2012;5(6):475-85.

62. Geiger P, Mayer B, Wiest I, Schulze S, Jeschke U, Weissenbacher T. Binding of galectin- 1 to breast cancer cells MCF7 induces apoptosis and inhibition of proliferation in vitro in a $2 \mathrm{D}$ and 3D-cell culture model. BMC Cancer. 2016;16(1):870. doi:10.1186/s12885-016-2915-8.

63. Fischer U, Janicke RU, Schulze-Osthoff K. Many cuts to ruin: a comprehensive update of caspase substrates. Cell Death Differ. 2003;10(1):76-100. doi:10.1038/sj.cdd.4401160.

64. Taylor RC, Cullen SP, Martin SJ. Apoptosis: controlled demolition at the cellular level. Nat Rev Mol Cell Biol. 2008;9(3):231-41. doi:10.1038/nrm2312. 
65. Tomlinson GE, Chen TT, Stastny VA, Virmani AK, Spillman MA, Tonk V, et al. Characterization of a breast cancer cell line derived from a germ-line BRCA1 mutation carrier. Cancer Res. 1998;58(15):3237-42.

66. Coene ED, Hollinshead MS, Waeytens AA, Schelfhout VR, Eechaute WP, Shaw MK, et al. Phosphorylated BRCA1 is predominantly located in the nucleus and mitochondria. Mol Biol Cell. 2005;16(2):997-1010. doi:10.1091/mbc.E04-100895 .

67. Henderson BR. The BRCA1 breast cancer suppressor: regulation of transport, dynamics, and function at multiple subcellular locations. Scientifica (Cairo). 2012;2012:796808. doi:10.6064/ 2012/796808.

68. Henderson BR. Regulation of BRCA1, BRCA2 and BARD1 intracellular trafficking. BioEssays. 2005;27(9):884-93. doi:10. 1002/bies.20277.

69. Feng Z, Kachnic L, Zhang J, Powell SN, Xia F. DNA damage induces p53-dependent BRCA1 nuclear export. J Biol Chem. 2004;279(27):28574-84. doi:10.1074/jbc.M404137200.

70. Perez-Valles A, Martorell-Cebollada M, Nogueira-Vazquez E, Garcia-Garcia JA, Fuster-Diana E. The usefulness of antibodies to the BRCA1 protein in detecting the mutated BRCA1 gene. An immunohistochemical study. J Clin Pathol. 2001;54(6):476-80.

71. Milner R, Wombwell H, Eckersley S, Barnes D, Warwicker J, Van Dorp E, et al. Validation of the BRCA1 antibody MS110 and the utility of BRCA1 as a patient selection biomarker in immunohistochemical analysis of breast and ovarian tumours. Virchows Arch. 2013;462(3):269-79. doi:10.1007/s00428-0121368-y.

72. Wei JT, Huang WH, Du CW, Qiu SQ, Wei XL, Liu J, et al. Clinicopathological features and prognostic factors of young breast cancers in Eastern Guangdong of China. Sci Rep. 2014;4:5360. doi:10.1038/srep05360.

73. Qu Y, Han B, Yu Y, Yao W, Bose S, Karlan BY, et al. Evaluation of MCF10A as a reliable model for normal human mammary epithelial cells. PLoS One. 2015;10(7):e0131285. doi:10.1371/journal.pone.0131285.

74. Dent R, Trudeau M, Pritchard KI, Hanna WM, Kahn HK, Sawka $\mathrm{CA}$, et al. Triple-negative breast cancer: clinical features and patterns of recurrence. Clin Cancer Res. 2007;13(15 Pt 1):4429-34. doi:10.1158/1078-0432.CCR-06-3045.

75. Foulkes WD, Smith IE, Reis-Filho JS. Triple-negative breast cancer. N Engl J Med. 2010;363(20):1938-48. doi:10.1056/ NEJMra1001389.

76. Chacon RD, Costanzo MV. Triple-negative breast cancer. Breast Cancer Res. 2010;12(Suppl 2):S3. doi:10.1186/bcr2574.

77. Foulkes WD, Stefansson IM, Chappuis PO, Begin LR, Goffin JR, Wong N, et al. Germline BRCA1 mutations and a basal epithelial phenotype in breast cancer. J Natl Cancer Inst. 2003;95(19):1482-5.

78. Bordeaux J, Welsh A, Agarwal S, Killiam E, Baquero M, Hanna $\mathrm{J}$, et al. Antibody validation. Biotechniques. 2010;48(3): 197-209. doi:10.2144/000113382.

79. Chambon M, Nirde P, Gleizes M, Roger P, Vignon F. Localization of BRCA1 protein in human breast cancer cells. Breast Cancer Res Treat. 2003;79(1):107-19.

80. Fabbro M, Henderson BR. Regulation of tumor suppressors by nuclear-cytoplasmic shuttling. Exp Cell Res. 2003;282(2): $59-69$.

81. Thompson ME. BRCA1 16 years later: nuclear import and export processes. FEBS J. 2010;277(15):3072-8. doi:10.1111/j. 1742-4658.2010.07733.x.

82. Rodriguez JA, Henderson BR. Identification of a functional nuclear export sequence in BRCA1. J Biol Chem. 2000;275(49): 38589-96. doi:10.1074/jbc.M003851200.
83. Madjd Z, Karimi A, Molanae S, Asadi-Lari M. BRCA1 Protein expression level and CD44(+)phenotype in breast cancer patients. Cell J. 2011;13(3):155-62.

84. Montecucco A, Biamonti G. Cellular response to etoposide treatment. Cancer Lett. 2007;252(1):9-18. doi:10.1016/j.canlet. 2006.11.005.

85. Yuan P, Di L, Zhang X, Yan M, Wan D, Li L, et al. Efficacy of oral etoposide in pretreated metastatic breast cancer: a multicenter phase 2 study. Medicine (Baltimore). 2015;94(17):e774. doi:10.1097/MD.0000000000000774.

86. Valabrega G, Berrino G, Milani A, Aglietta M, Montemurro F. A retrospective analysis of the activity and safety of oral Etoposide in heavily pretreated metastatic breast cancer patients. Breast J. 2015;21(3):241-5. doi:10.1111/tbj.12398.

87. Habbel P, Kurreck A, Schulz CO, Regierer AC, Kaul D, Scholz $\mathrm{CW}$, et al. Cisplatin plus ifosfamide with/without etoposide as salvage treatment in heavily-pre-treated patients with metastatic breast cancer. Anticancer Res. 2015;35(9):5091-5.

88. Wu PF, Lin CH, Kuo CH, Chen WW, Yeh DC, Liao HW, et al. A pilot study of bevacizumab combined with etoposide and cisplatin in breast cancer patients with leptomeningeal carcinomatosis. BMC Cancer. 2015;15:299. doi:10.1186/s12885-0151290-1.

89. Jun DW, Hwang M, Kim YH, Kim KT, Kim S, Lee CH. DDRI9: a novel DNA damage response inhibitor that blocks mitotic progression. Oncotarget. 2016;7(14):17699-710. doi:10.18632/ oncotarget.7135.

90. Wu YH, Hong CW, Wang YC, Huang WJ, Yeh YL, Wang BJ, et al. A novel histone deacetylase inhibitor TMU-35435 enhances etoposide cytotoxicity through the proteasomal degradation of DNA-PKcs in triple-negative breast cancer. Cancer Lett. 2017. doi:10.1016/j.canlet.2017.04.023.

91. Shin SY, Kim CG, Lee YH. Egr-1 regulates the transcription of the BRCA1 gene by etoposide. BMB Rep. 2013;46(2):92-6.

92. Fan S, Twu NF, Wang JA, Yuan RQ, Andres J, Goldberg ID, et al. Down-regulation of BRCA1 and BRCA2 in human ovarian cancer cells exposed to adriamycin and ultraviolet radiation. Int J Cancer. 1998;77(4):600-9.

93. Kroupis C, Stathopoulou A, Zygalaki E, Ferekidou L, Talieri M, Lianidou ES. Development and applications of a real-time quantitative RT-PCR method (QRT-PCR) for BRCA1 mRNA. Clin Biochem. 2005;38(1):50-7. doi:10.1016/j.clinbiochem. 2004.09.012.

94. Laulier C, Barascu A, Guirouilh-Barbat J, Pennarun G, Le Chalony C, Chevalier F, et al. Bcl-2 inhibits nuclear homologous recombination by localizing BRCA1 to the endomembranes. Cancer Res. 2011;71(10):3590-602. doi:10.1158/00085472.CAN-10-3119.

95. Jia Y, Song W, Zhang F, Yan J, Yang Q. Akt1 inhibits homologous recombination in Brca1-deficient cells by blocking the Chk1-Rad51 pathway. Oncogene. 2013;32(15):1943-9. doi:10.1038/onc.2012.211.

96. Plo I, Laulier C, Gauthier L, Lebrun F, Calvo F, Lopez BS. AKT1 inhibits homologous recombination by inducing cytoplasmic retention of BRCA1 and RAD51. Cancer Res. 2008;68(22):9404-12. doi:10.1158/0008-5472.CAN-08-0861.

97. Fabbro M, Schuechner S, Au WW, Henderson BR. BARD1 regulates BRCA1 apoptotic function by a mechanism involving nuclear retention. Exp Cell Res. 2004;298(2):661-73. doi:10. 1016/j.yexcr.2004.05.004.

98. Shao N, Chai YL, Shyam E, Reddy P, Rao VN. Induction of apoptosis by the tumor suppressor protein BRCA1. Oncogene. 1996;13(1):1-7.

99. Zhang H, Somasundaram K, Peng Y, Tian H, Zhang H, Bi D, et al. BRCA1 physically associates with p53 and stimulates its 
transcriptional activity. Oncogene. 1998;16(13):1713-21. doi:10.1038/sj.onc.1201932.

100. Chai YL, Cui J, Shao N, Shyam E, Reddy P, Rao VN. The second BRCT domain of BRCA1 proteins interacts with p53 and stimulates transcription from the p21WAF1/CIP1 promoter. Oncogene. 1999;18(1):263-8. doi:10.1038/sj.onc.1202323.

101. MacLachlan TK, Takimoto R, El-Deiry WS. BRCA1 directs a selective p53-dependent transcriptional response towards growth arrest and DNA repair targets. Mol Cell Biol. 2002;22(12):4280-92.

102. Arizti P, Fang L, Park I, Yin Y, Solomon E, Ouchi T, et al. Tumor suppressor p53 is required to modulate BRCA1 expression. Mol Cell Biol. 2000;20(20):7450-9.

103. Wasielewski M, Elstrodt F, Klijn JG, Berns EM, Schutte M. Thirteen new p53 gene mutants identified among 41 human breast cancer cell lines. Breast Cancer Res Treat. 2006;99(1):97-101. doi:10.1007/s10549-006-9186-z.

104. Fedier A, Steiner RA, Schwarz VA, Lenherr L, Haller U, Fink D. The effect of loss of Brcal on the sensitivity to anticancer agents in p53-deficient cells. Int J Oncol. 2003;22(5):1169-73.

105. Wang H, Yang ES, Jiang J, Nowsheen S, Xia F. DNA damageinduced cytotoxicity is dissociated from BRCA1's DNA repair function but is dependent on its cytosolic accumulation. Cancer Res. 2010;70(15):6258-67. doi:10.1158/0008-5472.CAN-094713.

106. Jiang J, Yang ES, Jiang G, Nowsheen S, Wang H, Wang T, et al. p53-dependent BRCA1 nuclear export controls cellular susceptibility to DNA damage. Cancer Res. 2011;71(16):5546-57. doi:10.1158/0008-5472.CAN-10-3423.

107. Chen J. Ataxia telangiectasia-related protein is involved in the phosphorylation of BRCA1 following deoxyribonucleic acid damage. Cancer Res. 2000;60(18):5037-9.

108. Tibbetts RS, Cortez D, Brumbaugh KM, Scully R, Livingston D, Elledge SJ, et al. Functional interactions between BRCA1 and the checkpoint kinase ATR during genotoxic stress. Genes Dev. 2000;14(23):2989-3002.

109. Gatei M, Zhou BB, Hobson K, Scott S, Young D, Khanna KK. Ataxia telangiectasia mutated (ATM) kinase and ATM and Rad3 related kinase mediate phosphorylation of Brca1 at distinct and overlapping sites. In vivo assessment using phospho-specific antibodies. J Biol Chem. 2001;276(20):17276-80. doi:10.1074/ jbc.M011681200.

110. Martin SA, Ouchi T. BRCA1 phosphorylation regulates caspase-3 activation in UV-induced apoptosis. Cancer Res. 2005;65(23):10657-62. doi:10.1158/0008-5472.CAN-05-2087.

111. Gudmundsdottir K, Ashworth A. The roles of BRCA1 and BRCA2 and associated proteins in the maintenance of genomic stability. Oncogene. 2006;25(43):5864-74. doi:10.1038/sj.onc. 1209874.

112. Uhlen M. Response to: should we ignore western blots when selecting antibodies for other applications? [letter]. Nat Methods. 2017;14(3):215-6. doi:10.1038/nmeth.4194.

113. Waddell N, Arnold J, Cocciardi S, da Silva L, Marsh A, Riley J, et al. Subtypes of familial breast tumours revealed by expression and copy number profiling. Breast Cancer Res Treat. 2010;123(3):661-77. doi:10.1007/s10549-009-0653-1.

114. Naipal KA, Verkaik NS, Ameziane N, van Deurzen CH, Ter Brugge P, Meijers M, et al. Functional ex vivo assay to select homologous recombination-deficient breast tumors for PARP inhibitor treatment. Clin Cancer Res. 2014;20(18):4816-26. doi:10.1158/1078-0432.CCR-14-0571.

115. von Wahlde MK, Timms KM, Chagpar A, Wali VB, Jiang T, Bossuyt $\mathrm{V}$, et al. Intratumor heterogeneity of homologous recombination deficiency in primary breast cancer. Clin Cancer Res. 2017;23(5):1193-9. doi:10.1158/1078-0432.CCR-16-0889.

116. Da Silva L, Lakhani SR. Pathology of hereditary breast cancer. Mod Pathol. 2010;23(Suppl 2):S46-51. doi:10.1038/modpathol. 2010.37.

117. Wang D, Du R, Liu S. Rad51 inhibition sensitizes breast cancer stem cells to PARP inhibitor in triple-negative breast cancer. Chin J Cancer. 2017;36(1):37. doi:10.1186/s40880-017-0204-9.

118. Lord CJ, Ashworth A. PARP inhibitors: synthetic lethality in the clinic. Science. 2017;355(6330):1152-8. doi:10.1126/science. aam7344.

119. Furgason JM, Bahassi El M. Targeting DNA repair mechanisms in cancer. Pharmacol Ther. 2013;137(3):298-308. doi:10.1016/j. pharmthera.2012.10.009. 